\title{
PENERAPAN ACCRUAL BASIS PADA PELAPORAN KEUANGAN UMKM BERDASARKAN SAK ETAP DI KOPERASI KARYAWAN PT. BANK SULUT
}

\author{
Agita Motto $^{1}$, Ventje Ilat ${ }^{2}$, Meyli Kalalo ${ }^{3}$ \\ ${ }^{1,2,3}$ Fakultas Ekonomi dan Bisnis, Jurusan Akuntansi, Universitas Sam Ratulangi, Jl. Kampus Bahu, Manado, \\ 95115, Indonesia
}

E-mail : agita_motto@yahoo.com

\begin{abstract}
MSME is regulated based on Law No. 20 Year 2008 on Micro Small Medium Enterprises. In practice in the field of many MSMEs pelaprannya not adequate because sebagia still use the cash basis in penyilasianya and presentation of financial statements. Financial reporting of MSMEs should be prepared based on SAK ETAP and using accrual basis. The purpose of this research is to apply financial report of Cooperative UMKM based on SAK ETAP. The research method used is descriptive qualitative, where the qualitative data is the information data in the form of verbal sentence is not a symbol of numbers or numbers. Qualitative data obtained through a process using in-depth analysis techniques and can not be obtained directly. The results showed that the Employee Cooperation of PT.Bank Sulut which broperasi field of Java that is saving and loan services as well as vehicle rental, cloth factory. Transactions are recorded on an accrual basis system where transactions are recognized when they occur rather than when cash is received.
\end{abstract}

Keywords: MSME, Financial Statement, SAK ETAP

\section{PENDAHULUAN}

UMKM adalah singkatan dari Usaha Mikro Kecil dan Menengah. UMKM diatur berdasarkan Undang-Undang Nomor 20 Tahun 2008 tentang Usaha Mikro Kecil Menengah. Usaha kecil adalah usaha ekonomi produktif yang berdiri sendiri, yang dilakukan oleh perorangan atau badan yang bukan merupakan anak perusahaan atau bukan cabang perusahaan yang dimiliki, dikuasai ataupun menjadi bagian baik langsung dari usaha menengah atau usaha besar yang memenuhi kriteria usaha kecil sebagaimana dimaksud dalam undang-undang. UMKM di Indonesia berkembang sangat pesat. Berdasarkan data Departemen Koperasi dari tahun 2011-2012 PDB (Produk Domesik Bruto) dari UMKM meningkat sebesar $12,67 \%$. Ini menandakan pendapatan dari industri ini sangat menjanjikan dimasa yang akan datang. Ada potensi bahwa UMKM akan menjadi besar dimasa datang, dengan operasi bisnis yang lebih kompleks. Pada laporan keuangan ada 2 metode pencatatan akuntansi ,kas dan berbasis akrual. Basis akrual adalah penyandingan pendapatan dan biaya pada periode disaat terjadinya, bukan pencatatan pada saat pendapatan tersebut diterima ataupun biaya tersebut dibayarkan (cash basis). Akuntansi berbasis kas berarti hanya mencatat transaksi pada saat terjadinya transaksi kas, basis akrual selain mencatat transaksi pengeluaran dan penerimaan kas, juga mencatat hutang dan piutang organisasi. Oleh karena itu, akuntansi berbasis akrual memberikan gambaran yang lebih akurat atas kondisi keuangan organisasi daripada akuntansi berbasis kas. Namun jelas bahwa catatan menggunakan basis akrual lebih kompleks daripada basis kas. Dalam prakteknya, di lapangan banyak UMKM yang pelaporannya belum memadai karena sebagian besar masih menggunakan basis kas dalam penyususnan dan penyajian laporan keuangannya. Kompleksitas akuntansi berbasis akrual merupakan salah satu hal yang dapat menjadihambatan dan menjadi salah satu alasan timbulnya penolakan terhadap perubahan basis akuntansi (Najati, 2016). Pelaporan keuangan UMKM sebaiknya disusun berdasarkan SAK ETAP dan menggunakan basis akrual. Namum 
di beberapa UMKM masih menerapkan penyusunan laporan keuangan berbasis kas dan hal tersebut tidak sesuai dengan ketentuan SAK ETAP. Kehadiran SAK ETAP diharapkan dapat memberikan kemudahan dalam menyajikan laporan keuanga bagi entitas tanpa akuntabilitas publik. Tujuan dari SAK ETAP sendiri yakni untuk memberikan kemudahan bagi entitas skala kecil dan menengah (sagala, 2014). SAK ETAP sendiri dibuat untuk mengatasi segala keluhan penerapan PSAK umu pada entitas tanpa akuntabilitas publik.

SAK ETAP bertujuan untuk mengakomodir segala kebutuhan entitas tanpa akuntabilitas publik dalam pelaporan keuangan. Berdasarkan hal tersebut maka sudah seharusnya entitas tanpa akuntabilitas publik menerapkan SAK ETAP dalam menyajikan laporan keuangannya. Tetapi berdasarkan kenyataan di lapangan masih banyak Entitas Tanpa Akuntabilitas Publik yang tidak memadai pencatatannya, seperti objek penelitian Hapsari (2013) yang menemukan bahwa pelaporan keuangan pada objek penelitian belum menerapkan SAK ETAP. Di daerah Sulawesi Utara masih banyak koperasi yang belum menetapkan SAK ETAP. Padahal SAK ETAP dibuat untuk mempermudah operasi bisnis koperasi terutama dalam hubungannya dengan pihak eksternal. Koperasi Karyawan PT. Bank Sulut termasuk dalam golongan entitas tanpa akuntabilitas publik sehingga untuk menghasilkan laporan keuangan yang berkualitas maka dalam menyajikan laporan keuangannya perlu menerapkan SAK ETAP. Diharapkan melalui penelitian ini Koperasi Karyawan PT. Bank Sulut dapat menerapkan SAK ETAP untuk penyusunan dan penyajian laporan keuangannya. Berdasarkan masalah yang telah diuraikan, maka tujuan dari penelitian ini adalah untuk menerapkan laporan Keuangan UMKM Koperasi berdasarkan SAK ETAP di koperasi karyawan PT. Bank sulut.

\section{TINJAUAN PUSTAKA}

\section{1. Konsep Akuntansi}

Menurut Taswan didalam Ismail (2015:2) bisa di definisikan sebagai seni, ilmu, sistem informasi yang didalamnya menyangkut pencatatan, penglassifikasian, dan pengikhtisaran denga caea sepatutnya dan dalam satuan uang transaksi dan kejadian yang setidak-tidaknya sabagian mempunyai sifat keuangan serta adanya pengiterprestasian hasil pencatatan dan disajikan dalam laporan keuangan. Menurut Wilsson, et al (2015:4) akuntansi adalah proses pengumpulan, pengklasifikasian, pencatatan, pelaporan, pengiterpretasian dan analisis dampak dari transaksi keuangan pada suatu bisnis atau organisasi untuk menyediakan informasi kepada pemilik manajemen dan pihak yang membutuhkan lainnya.

\subsection{Akuntansi Keuangan}

Pengguna eksternal dari informasi akuntansi adalah investor kreditor pelanggan dan pemerintah (Warren, 2017:6). Para pengguna ini tidak secara langsung terlibat dalam mengatur dan mengoprasikan bisnis.

Aset $=$ Liabilitas + Ekuitas

Produk akhir dari akuntansi keuangan adalah laporan keuangan. Menurut

Weygandt, et al (2013:22) perusahaan akan menyiapkan 4 jenis laporan keuangan untuk menunjukan kinerja perusahaan yaitu :

1. Laporan laba rugi yang menyajikan jumlah pendapatan dan jumlah beban serta menyajikan hasil dalam bentuk laba atau rugi selama periode tertentu.

2. Laporan laba ditahan yang menyajian perubahan pada akun laba ditahan selama periode tertentu.

3. Laporan posisi keuangan atau biasa disebut neraca yang menyajikan posisi keuangan perusahaan yaitu jumlah aset perusahaan kewajiban perusahaan dan modal perusahaan pertanggal tertentu. 
4. Laporan arus kas yang menyajikan informasi tentang arus kas masuk atau penerimaan dalam bentuk kas dan arus kas keluar atau pengeluaran dalam bentuk kas selama periode tertentu.

\section{3. Konsep Accrual Basis}

Menurut Ruppel (2012:43) basis dari akuntansi menunjuk pada pertanyaan kapan pendapatan pengeluaran beban dan transfer (terkait dengan aset dan liabilitas) diakui dan dilaporkan dalam laporan keuangan. Kebanyakan dari akuntan cukup terbiasa dengan basis kas dan basis akrual dari akuntansi. Kebanyakan perusahaan komersial pada umumnya menggunakan basis akrual untuk membuat laporan keuangan.

1. Cash Basis

Menurut Ruppel (2012:43) dibawah cash basis dari akuntansi pendapatan dan pengeluaran dicatat ketika kas diterima atau dibayarkan. Contohnya sebuah perusahaan membeli barang yang diterima dan digunakan oleh perusahaan. Namun demikian tagihan dari barang tersebut tidak dibayarkan sampai 2 bulan setelah barang diterima. Dibawah cash basis beban dari pembelian barang tersebut tidak diakui didalam laporan keuangan sampai tagihan tersebut dibayarkan walaupun ketika diterima barang itu telah dikonsumsi oleh perusahaan.

2. Accrual Basis

Menurut Kristiawati (2015) akuntansi berbasis akrual berarti suatu basis akuntansi di mana transaksi ekonomi dan peristiwa-peristiwa lain diakui dan dicatat dalam catatan akuntansi dan dilaporkan. Accrual basis pada umumnya diakui lebih baik dari pada metode cash basis baik diorganisasi komersial dan pemerintahan..

\section{4. Koperasi}

Menurut Wijatno (2009:117) koperasi adalah badan usaha yang beranggotakan orangorang atau badan hukum yang melaksanakan kegiatan berdasarkan asas kekeluargaan dan kegotongroyongan. Karakteristirk utama koperasi yang unik adalah bahwa anggota koperasi memiliki identitas ganda dimana anggota koperasi merupakan pemilik sekaligus pengguna jasa koperasi. Selisih keuntungan yang diperoleh koperasi dibagikan kepada anggota yang disebut Sisa Hasil Usaha (SHU).

Menurut UU No 25 tahun 1992 fungsi dan peran koperasi adalah sebagai berikut :

1. Membangun dan mengembangtkan potensi dan kemampuan anggota pada khususnya dan masyarakat pada umunya untuk meningkatkan ekonomi dan sosialnya

2. Berperan serta secara aktif dalam upaya mempertinggi kualitas kehidupan manusia dan masyarakat

3. Memperkokoh perekonomian rakyat sebagai dasar kekuatan dan ketahanan perekonomian nasional dengan koperasi sebagai sokohgurunya.

4. Berusaha untuk mewujudkan dan mengambangkan perekonomian nasional yang merupakan usaha bersama berdasarkan asas kekeluargaan demokrasi dan ekonomi

Selanjutnya menurut UU no 25 tahun 1992 pada pasal yang ke-5 prinsip koperasi adalah sebagai berikut :

1. Keanggotaanya bersifat sukarela dan terbuka

2. Pengelolaan bersifat demokratis

3. Pembagian sisa hasil usaha dibagikan secara adil sesuai partisipasi anggota

4. Pemberian balas jasa terbatas terhadap modal

5. Kemandirian

6. Pendidikan perkorasian

7. Kerjasama antar koperasi 


\section{METODE PENELITIAN}

\subsection{Jenis Penelitian}

Penelitian ini menggunakan penelitian kualitatif . Menurut Clifford, et al (2013:76) penelitian kualitatif masuk kedalam kategori desain penelitian deskriptif yang fokusnya adalah untuk menemukan apa yang terjadi pada situasi tertentu ketimbang mencoba menjelaskan hubungan atau penyebab dan akibat namun hal ini menyebabkan sebuah kebingungan karena desain penelitian deskriptif juga dapat digunakan dalam penelitian kuntitatif seperti menggunakan survei dimana data bisa di analisis secara numerikal.

\subsection{Metode Analisis}

Penelitian ini merupakan penelitian yang bersifat deskriptif dengan tujuan untuk memberikan gambaran yang mendetail tentang latar belakang, sifat-sifat serta karakteristik yang khas dari subjek penelitian.

\section{HASIL PENELITIAN}

\subsection{Proses Bisnis Perusahaan}

Koperasi Karyawan PT. Bank Sulut Go yang beroperasi di bidang jasa yaitu Jasa Simpan Pinjam dan juga Jasa Penyewaan Kendaraan, Pabrik Cetak Kain Batik. Transaksi simpan pinjam dicatat ketika transaksi terjadi, ketika transaksi peminjaman terjadi maka akun piutang pinjaman akan di debet dan ketika hutang dilunasi oleh peminjam maka piutang akan dihapus. Transaksi penyewaan kendaraan dicatat setiap 3 bulan sekali ketika kas diterima hasil perjanjian penyewaan kendaraan dilakukan dan kas dibayarkan, Usaha penyewaan kendaraan hanya dikhususkan kepada jajaran pejabat PT. Bank SulutGo. Hal ini merupakan kerjasama antara koperasi Karyawan Bank Sulut dan PT. Bank SulutGo. Simpan pinjam hanya berlaku untuk internal Bank Sulut, dengan bunga pinjaman 2\%. Sedangkan untuk Pabrik Pakaian Kantor beban operasional dicatat terjadi bukaan saat kas dibayarkan demikian pula dengan pendapatan di akui pada saat terjadi kesepakatan antara pihak koperasi dan langganannya.

\subsection{Pencatatan Transaksi}

Transaksi dicatat dengan sistem accrual basis dimana transaksi diakui ketika terjadi bukan saat kas diterima. Pencatatan transaksi pinjaman didebetkan pada akun piutang usaha yang terdiri dari piutang barang untuk transaksi peminjaman barang dari koperasi, piutang pinjaman untuk transaksi peminjaman kas dari koperasi karyawan PT Bank Sulut, dan piutang usaha pabrik kain untuk transaksi piutang usaha dari operasi pabrik kain. Laporan keuangan dibuat setiap bulan sesuai dengan SAK ETAP. Transaksi dicatat sesuai dengan bukti transaksi yang diberikan oleh kasir, kemudian dibuatkan jurnal umum yang lalu diposting ke buku besar, sesuai dengan akun-akunnya. Pencatatan transaksi dicatat sesuai dengan siklus akuntansi hingga penerbitan laporan keuangan dan pembuatan neraca saldo setelah penutupan.

Laporan keuangan yang dibuat oleh perusahaan lengkap yang terdiri dari :

1. Laporan Laba Rugi

2. Laporan Perubahan Ekuitas

3. Neraca

4. Laporan Arus Kas

\subsubsection{Pengendalian Internal}

Pengendalian internal untuk kas dilakukan dengan cara memisahkan kas kecil dan kas besar, juga melakukan pembedaan tugas antara yang mencatat transaksi dengan yang memegang kas.

\subsubsection{Laporan Keuangan}

Koperasi Karyawan Bank Sulut menggunakan dasar akrual untuk membuat laporan keuangannya. Laporan keuagan dibuat 1 bulan sekali dan menyajikan informasi komparatif 
untuk laporan laba rugi, laporan posisi keuangan, laporan perubahan ekuitas dan laporan arus kas.

\subsection{Pembahasan Hasil Penelitian \\ 4.3.1. Laporan Laba/Rugi}

Sesuai dengan standar akuntansi keuangan entitas tanpa akuntabilitas publik (SAK ETAP) informasi yang disajikan didalam laporan laba/rugi mencakup pos-pos pendapatan, beban keuangan, bagian laba/rugi dari investasi yang ,menggunakan metode ekuitas, beban pajak, serta laba/rugi neto (IAI :19). Entitas untuk menyajikan analisis menggunakan laporan laba ruginya yaitu :

\subsubsection{Laporan Posisi Keuangan}

Laporan posisi keuangan menyajikan aset kewajiban dan ekuitas suatu entitas pada suatu tanggal tertentu biasanya akhir periode Pelaporan, (IAI :15).

1. Aset

Entitas harus menyajikan aset lancar dan aset tidak lancar, kewajiban jangka pendek dan kewajiban jangka panjang sebagai suatu klasifikasi yang terpisah dalam neraca sesuai ketentuan SAK ETAP paragraf 46-49. entitas menglasifikasin aset sebagai aset lancar jika :

1. Diperkirakan akan direalisasi atau dimilki untuk dijual atau digunakan dalam jangka waktu siklus operasi normal entitas .

2. Dimilki untuk diperdagangkan.

3. Diharapkan akan direalisasi dalam jangka waktu 12 bulan setelah akhir periode pelaporan atau,

4. berupa kas atau setara kas kecuali jika dibatasi penggunaanya dari pertukaran atau digunakan untuk menyelesaikan kewajiban setidaknya 12 bulan setelah akhir periode pelaporan.

Entitas menglasifikasikan semua aset lainnya sebagain aset tidak lancar. Jika siklus operasi normal entitas tidak dapat di identifikasi dengan jelas maka siklus operasi diasumsikan 12 bulan. Pada Koperasi Karyawan PT Bank Sulut aset dikasifikasikan menjadi aset lancar dan aset tidak lancar dimana aset tidak lancar terdiri dari investasi jangka panjang, aset tetap dan aset lainnya. Untuk penyajian aset perusahaan sudah sesuai dengan SAK ETAP revisi 2016.

2. Kewajiban

Sesuai dengan SAK ETAP entitas harus menglasifikasikan kewajiban menjadi kewajiban jangka pendek dan kewajiban jangka panjang. Kewajiban dikasifikasian sebagai kewajiban jangka pendek jika :

1. Diperkirakan akan diselesaikan dalam jangka waktu siklus normal operasi entitas

2. Dimiliki untuk diperdagangkan

3. Kewajiban akan diselesaikan dalam jangka waktu 12 bulan setelah akhir periode pelaporan atau

4. Entitas tidak memiliki hak tanpa syarat untuk menunda penyelesaian kewajiban setidaknya 12 bulan setelah akhir peiode pelaporan.

Pada Koperasi Karyawan PT Bank Sulut kewajiban diklasifikasi menjadi kewajiban jangka pendek dan kewajiban jangka panjang hal ini sudah sesuai dengan SAK ETAP revisi 2016. Untuk ekuitas tidak terdapat persyaratan untuk klasifikasi ekuitas. Pada Koperasi Karyawan PT Bank Sulut ekuitas terdiri dari simpanan pokok, simpanan wajib, simpanan saham, dana setoran modal, dana cadangan, SHU tahun berjalan, dan SHU yang belum dibagi, dapat disimpulkan bahwa ekuitas sudah disajikan sesuai SAK ETAP revisi 2016. Laporan posisi keuangan sudah disajikan SAK ETAP revisi 2016 kecuali laporan tidak menyajikan informasi komparatif periode sebelumnya.

\subsubsection{Laporan Perubahan Ekuitas}

Laporan perubahan ekuitas menyajikan laba/rugi entitas untuk suatu periode, pos pendapatan beban yang diakui secara langsung dalam ekuitas untuk periode tersebut, 
pengaruh perubahan kebijakan akuntansi dan koreksi kesalahan yang di akui periode tersebut dan jumlah investasi oleh dan deviden yang distribusi lain ke, pemilik ekuitas selama periode tersebut (IAI : 21).

Entitas menyajikan laporan perubahan ekuitas yang menunjukan :

Laba/Rugi untuk periode

1. Pendapatan atau beban yang diakui langsung dalam ekuitas

2. Untuk setiap komponen ekuitas, pengaruh perubahan kebijakan akuntansi dan koreksi kesalahan yang diakui sesuai kebijakan akuntansi estimasi dan kesalahan

3. Untuk setiap komponen ekuitas, suatu rekonsiliasi antara jumlah tercatat awal dan akhir periode diuangkapkan secara terpisah perubahan yang berasal dari :

\subsubsection{Laporan Arus Kas}

Laporan arus kas menginformasi perubahan historis atas kas dan setara kas entitas yang menunjukan secara terpisah perbuhan yang terjadi selama 1 periode dari aktivitas operasi investasi dan pendanaan

\section{Aktivitas Operasi}

Arus kas dan aktivias operasi terutama diperoleh dari aktivitas penghasil utama pendapatan entitas. Oleh karena itu arus kas tersebut pada umumnya berasal dari transaksi dan peristiwa dan kondisi lain yang mempengaruhi penetapan laba atau rugi .

2. Aktivitas Investasi

Arus kas dari aktivitas investasi mencerminkan pengeluaran kas sehubungan dengan sumber daya yang bertujuan untuk menghasilkan pendapatan dan arus kas masa

3. Aktivitas Pendanaan

Contoh arus kas yang berasal dari aktivitas pendanaan adalah :

1. penerimaan kas dari penerbitan saham atau efek ekuitas lain

2. pembayaran kas kepada para pemegang saham untuk menarik atau menebus saham entitas

3. penerimaan kas dari penerbitan pinjaman, wesel dan pinjaman jangka pendek atau pinjaman jangka panjang lainnya

4. pelunasan pinjaman

5.pembayaran kas oleh lessee untuk mengurangi saldo kewajiban yang berkaitan dengan sewa pembiayaan

Dalam laporan arus kas terdapat informasi komparatif periode sebelumnya sebagai perbandingan untuk angka-angka pada periode saat ini. Dapat disimpulkan bahwa koperasi Karyawan PT Bank Sulut telah menyusun laporan arus kas sesuai dengan SAK ETAP revisi 2016.

Dua jenis kategori penyesuaian dasar adalah Pembayaran Dimuka (prepayments) dan Penangguhan (Accrued). Ada lima jenis jurnal penyesuaian di akhir periode yaitu :

1. Beban dibayar dimuka

2. Penyusutan dari aktiva tidak lancar

3. Accrued Expenses/Beban Terutang

4. Accrued Revenue/Pendapatan yang masih harus diterima

5. Pendapatan diterima dimuka

(Horngren, 2012: 119)

\section{KESIMPULAN DAN SARAN}

\subsection{Kesimpulan}

1. Laporan keuangan disajikan sesuai dengan frekuensi periode pelaporan yaitu minimal setahun sekali.

2. Laporan keuangan yang dibuat koperasi karyawan PT Bank Sulut lengkap sesuai dengan anjuran SAK ETAP. 
3. Basis yang digunakan dalam pencatatan akuntansi entitas adalah basis akrual.

4. Entitas memiliki catatan atas laporan keuangan untuk menjelaskan angka-angka yang ada dalam laporan keuangan.

\subsection{Saran}

Berdasarkan hasil penelitian dan pembahasan serta kesimpulan maka saran yang dapat disampaikan adalah :

1. Tetap menerapkan SAK ETAP.

2. Entitas diharapkan tetap terus membuat laporan keuangan yang sudah sesuai dengan SAK ETAP.

3. Dapat mempertimbangkan untuk menerapkan SAK Beban IFRS.

\section{DAFTAR PUSTAKA}

Clifford, Shaearing, Les John Ston. (2013). Innovative Possibbilities: Global Policing Research and Practice. Routledge. New York

Hapsari, Mia. 2013. Implementasi Laporan Keuangan Sesuai SAK ETAP (Standar Akuntansi Keuangan Entitas Tanpa Akuntabilitas Publik) pada CV. Sapta Putera Mekar. Universitas Komputer Indonesia Bandung

Horngren, C., Harrison , W., Olive , S., Best, P., Fraser, D., Tan, R., et al. (2012). Accounting. Australia: Pearson Higher Education.

I. A. I. (2015). Pernyataan standar Akuntansi Keuangan. Jakarta.

Ismail. 2015. Akuntansi Bank : Teori dan Aplikasi dalam Rupiah. Prenada Media. Jakarta.

Kristiawati, Endang. (2015) Faktor-faktor yang mempengaruhi keberhasilan penerapan akuntansi Berbasis Akrual pada Pemerintahan Dearah Kalimantan Barat. Akuntabilitas Vol. VIII No. 3, Hal 171-190

Najati, I.,Putringsih, E.,Animah. (2016). Implementasi Akuntansi Berbasis Accrual: pengujian Determinal dan Implikasih terhadap Kualitas Laporan Keuangan Kementerian/Lembaga. Jurnal akuntansi Universitas Jember 1-17.

Ruppel, Warren. 2012. Wiley GAAP For Goverment 2012: Interpretation and Application of Generally Accepted Accounting Principles for State end Local Goverment. John Wiley \& Sons.

Sagala, DelvianHorngren, C., Harrison , W., Olive , S., Best, P., Fraser, D., Tan, R., et al. (2012). Accounting. Australia: Pearson Higher Education.

Saragih, F., \& Surikayanti. (2015). Analisis Penerapan Akuntansi dan Kesesuainnya dengan SAK ETAP pada UKM Medan Perjuangan. Jurnal Universitas Negeri Padang.

Weygandt, Jerry, Paul D. Kimell, Donald E. Kieso. 2013. Financial Accounting: 7th Edition, John Willey \& Sons. Canada.

Warren, C. S., Reeve, J. M., \& Buchac, J. (2017). Financial Accounting. kanada: Cengage Learning.

Wilsson, V., Freeman, S., \& Freeman , J. (2015). Accounting : a Practical approach. Australia: Pearson Higher Education AU. 